\title{
INFO-COMMUNICATION EXPERTS IN THE DEFENCE SECTOR: VOCATIONAL TRAINING PROGRAM
}

\author{
Tibor FARKAS ${ }^{1}$, Erika HRONYECZ2 \\ ${ }^{1}$ National University of Public Service, Faculty of Military Sciences and Officer Training, Institute of Military \\ Maintenance, Department of Signaling, Budapest, Hungary, \\ farkas.tibor@uni-nke.hu \\ ${ }^{2}$ Óbuda University, Doctoral School on Safety and Security Sciences, Budapest, Hungary, \\ hronyecz.erika@bgk.uni-obuda.hu
}

\begin{abstract}
Nowadays, international and national events clearly point out the need for cooperation between different defense organizations in crisis and emergency situations (disaster events, migration issues, and other emergencies) for successful tasks. The fundamental basis of this cooperation is always the command and control activity supported by modern technical equipment that ensures the coordinated implementation of tasks. The key, human element of info-communication support is the preparation and training of the successful professionals. In this paper, the authors intend to present the importance of vocational training.
\end{abstract}

Keywords: IT, communication, defence sector, education, vocational training.

\section{Introduction}

Crisis and disaster situations on a national and international level constantly remind us that only through well synchronised cooperation and clearly defined leadership can their elimination and relief be achieved.

To this purpose, sharing information, and processing and providing that information to those in leadership is extremely vital. Furthermore, its execution gives the professionals involved in the planning and achievement of info-communication support, an certain amount of difficulty [1], [2].

Thus it can easily be seen, that next to technology, the info-communication personnel play a serious role in the realization of a successful outcome.

According to this, the education and further training of professional personnel is inevitable and is a relevant goal during the setting of future strategies.

\section{Background of shaping professional training}

During the relief of crisis situations, the given activity is performed by numerous organizations under a central coordination. All the organizations use their own communication systems to support the activity with success. In our view, the assumption of a broader cooperation is that the professional info-communication personnel (professional personnel further on) know the infocommunication system and abilities of all of the partaking organisations. Of course this can only be achieved through a thorough and sufficiently organised training that secures the preparation of each security and other type of organisations' professionals.

Further, this type of training would also enable the possibility of changing the assignment of professionals between the organisations, similarly to the future possible (civilian) public service employment of the professional (uniformed) 
personnel educated at National University of Public Service (NUPS further on).

Thus it makes decreasing fluctuation of infocommunication professionals from the public sphere possible, securing its stability through that.

\subsection{National directions of info-communica- tion development}

The „digital consolidation” of Hungary is a high priority element of national development, both on the field of governance and that of the society. In interest to this „National Info-communication Strategy 2014-2020" (NIS) document has been initialized, which draws the directions, possibilities and fields of info-communication sector. In our present paper we don't want to discuss the general development of the society's digital competency, only the further training of security professional personnel. Nonetheless, we understand that it as vital, that the training has to keep the guidelines of the info-communication strategy in sight. The document puts these goals as follows:

„The purpose of this strategy is to provide as coherent picture of the current situation of the Hungarian information society and, based on that, to lay down the development trends of the infocommunications sector, the public policy, regulatory and support activities for the same period as the 2014-2020 EU planning cycle, as well as to take into account the instruments/resources required for their implementation.” [3].

The strategy basically defines all those fields that have a great impact on the goals set. In accordance, it separates four pillars as follows (Figure 1.):

- digital infrastructure;

- digital competencies;

- digital economy;

- digital state.
These together shape the most important criteria, procedures and attributes, through which the development goals can be reached. Beyond that, three horizontal pillars have also been defined, like:

-e-hosting;

- Research, Development and Innovation;

- security.

During the analysis in this paper, digital infrastructure and digital state is of outstanding priority, and also security as horizontal factor. These are the partial fields which can be stood parallel to the training of the professional personnel.

Efficiency of the development was analysed by a review, with the outcome that however the development is going on above EU average, the realized services and the utilization of them according to the NIS pillars, show a significant drawback still. [4]

\subsection{Basis of the training}

Today, training and education of professionals for defence and security field and the organisations maintaining it are provided by the Faculties of NUPS, which maintains the training of „uniformed” and civilian professionals on BSc, MSc and PhD level and also in the frame of other trainings regarding the different fields. Beyond training and education, NUPS shares the tasks in the field of research, which is meant to secure the development of each field within public service. Most important directions and connection points of research are defined in each summarizing announcements by the two research colleges of NUPS (Military Science College of the University Research Committee; College of Engineering Science) [5] [6]. Info-communication research and development appear in both documents, but given by the nature of the field, it is more prominently stressed in the field of engineering. All these, to-
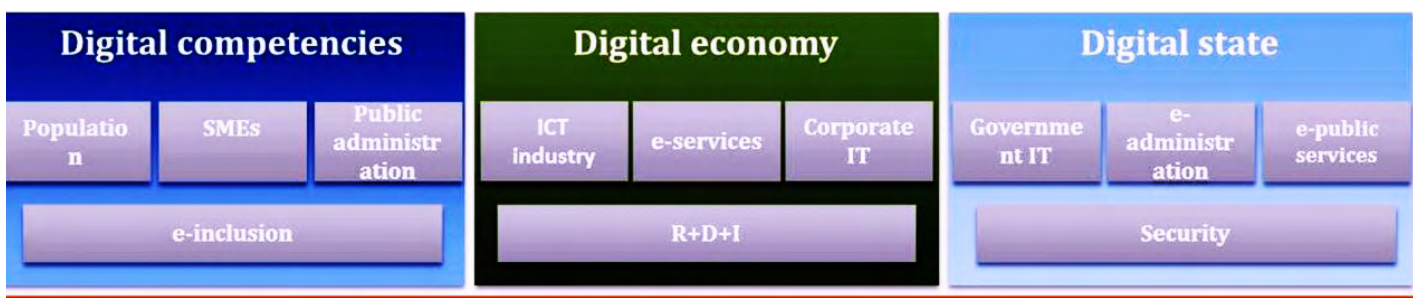

Digital infrastructure

Optical backbone network

Optical bachhaul network

Local networks (NGA)

Figure 1. Pillars of the National Infocommunications Strategy 
gether with those points defined in the Research, Development and Innovation Strategy support the presumption, that NUPS can be the number one basis of necessary training.

\section{Further professional training and the regulation defining it}

Info-communication experts working with the organisations of defence sphere (leaders on each level, and responsible persons) get their basic knowledge in different level education of different higher education institutes. Afterwards they broaden their knowledge by years of professional practice and different types of trainings, but mostly restricted to their own organisation only.

\subsection{Defining basic fields of further training}

Based on the above it is easy to see, that it's necessary to get to know info-communication systems, networks and technology (digital competency and infrastructure) of other public service and defence organisations, based on organising and planning principles. To this purpose, those infrastructure and system elements have to be defined, which can provide a basis for this knowledge. These can be the following fields:

- defence operations and the basis of their support;

-info-communication infrastructure;

-info-communication system planning and organising;

- governmental networks (based on 188/2016. (VII. 13.) Gov.ed.; a 346/2010. (XII. 28.) Gov.ed.); -information network of law enforcement organisations;

-separate information networks for governmental purposes (HDF network);

- public governance networks and systems;

- directions of development and strategy;

-information security.

\subsection{Documents defining the shape of furt- her training}

To this purpose, each regulation has to be kept in sight. The most important ones without a full list are:

- CCIV act of 2011. on national higher education; $-10 / 2006$. (IX. 25.) edict of OKM on the general terms of organising professional further training;

- Handout on the education and finalisation requirements of professional further trainings;

- NUPS Education and Exam Regulation, Organisation and Operation Regulation;
-Establishing of professional further training (registration of education and finalisation requirements);

- Handout on professional further trainings, General handout on the process of establishing and starting professional further trainings;

- Changing, deleting the data of registered training (responsible person, specialization, field of science, declaration, education and finalisation requirements).

\section{Conclusion}

The further trainings, that can be established to provide a qualification according to Act of National Higher Education, can greatly contribute to the constant further education of professionals, the possible reeducation of them, thus the increase of state info-communication sector efficiency. In our view, on the field of info-communication this is not given totally, thus this field has to be strengthened in the interest of increasing the level of knowledge competency. All these strengthen the contribution of NUPS as public service lecturer basis, to the innovation of public services. Possessing this type of knowledge increases the possibility of easier cooperation between each segments of public service info-communication sector, further it helps and eases the possible and necessary fluctuation of professionals within the state sector. Thus the creation of value and productivity have to be held in sight, which can be achieved by realising the further education of professionals, and by the creation of ability-based preparation, and meeting the regulation of law.

\section{Acknowledgement}

Supported by the ÚNKP-17-4-III-NKE-76 New National Excellence Program of the Ministry of Human Capacities.

\section{References}

[1] Farkas T., Hronyecz E.: Basic information needs in disaster situations (capabilities and requirements). In: A XXI. Fiatal műszakiak tudományos ülésszak előadásai. Proceedings of the 21th international scientific conference of youngth engineers, Kolozsvár/Cluj, Kolozsvár, Románia, Müszaki Tudományos Közlemények 5. (2016) 153-156.

https://eda.eme.ro/handle/10598/29161

[2] Farkas T.: A katasztrófavédelmi és válságkezelési tevékenységek általános elemzése az irányítás és az infokommunikációs támogatás tükrében. Hadmérnök 11/3. (2016) 135-148. 
[3] Hungarian government: National Infocommunicational Strategy 2014-2020; (Development Strategy of the Infocommunications Sector (20142020) v9.0), 2014.12.22., 10.

http://www.kormany.hu/download/5/ff/70000/ NIS_EN_clear.pdf

[4] Hungarian government: Nemzeti Infokommunikációs Stratégia 2016. évi monitoring jelentése, 2016, 162. (accessed: 2017.12.10.)

http://www.kormany.hu/download/d/22/21000/

NIS_monitoring_v\%C3\%A9gleges.pdf
[5] Bleszity J., Földi L.,; Haig Zs., Nemeslaki A., Restás Á.: Müszaki kutatások és hatékony kormányzás. Hadmérnök 11/3. (2016) 221-242. http://hadmernok.hu/163_18_bleszity.pdf

[6] Boda J., Boldizsár G., Kovács L., Orosz Z., Padányi J., Resperger I., Szenes Z.: Fókusz és együttmüködés. A hadtudomány kutatási feladatai. Honvédségi Szemle 144/3. (2016) 3-19. 